\title{
Regulation of Interferon-Stimulated Genes in Peripheral Blood Leukocytes in Pregnant and Bred, Nonpregnant Dairy Cows
}

\author{
C. A. Gifford, ${ }^{*}$ K. Racicot,† D. S. Clark, ${ }^{*}$ K. J. Austin,‡ T. R. Hansen,§ M. C. Lucy,\| \\ C. J. Davies,\# and T. L. Ott $\dagger^{1}$ \\ *Department of Animal and Veterinary Sciences, University of Idaho, Moscow 83844 \\ †Department of Dairy and Animal Science, The Pennsylvania State University, University Park 16802 \\ $\ddagger$ Department of Animal Science, University of Wyoming, Laramie 82071 \\ §Department of Biomedical Sciences, Colorado State University, Ft. Collins 80523 \\ |Department of Animal Science, University of Missouri, Columbia 65211 \\ \#Department of Veterinary Microbiology and Pathology, Washington State University, Pullman 99164
}

\section{ABSTRACT}

In ruminants, pregnancy results in up-regulation of a large number of IFN-stimulated genes (ISG) in the uterus. Recently, one of these genes was also shown to increase in peripheral blood leukocytes (PBL) during early pregnancy in sheep. Our working hypothesis is that conceptus signaling activates maternal gene expression in PBL in dairy cattle. The objectives of this study were to characterize ISG expression in PBL from pregnant $(\mathrm{n}=20)$ and bred, nonpregnant $(\mathrm{n}=30)$ dairy cows. Steady-state levels of mRNA for $\mathrm{Mx} 1, \mathrm{Mx} 2, \beta 2$ microglobulin, ISG-15, IFN regulatory factor-1, and IFN regulatory factor-2 were quantified. Holstein cows were synchronized to estrus and artificially inseminated (d 0 ). Blood samples were collected (coccygeal venipuncture) on $\mathrm{d} 0$ and 16, 18, and $20 \mathrm{~d}$ after insemination for progesterone analysis and PBL isolation. Pregnancy was confirmed by transrectal ultrasonography at approximately $40 \mathrm{~d}$ after breeding. A status $\times$ day interaction was detected for $\mathrm{Mx} 1, \mathrm{Mx} 2$, and ISG-15 gene expression. When analyzed within day, levels of mRNA for ISG-15 and $\mathrm{Mx} 1$ were greater in pregnant compared with bred, nonpregnant cows on d 18 and 20, respectively. Expression of the $\mathrm{Mx} 2$ gene increased in the pregnant group compared with bred, nonpregnant cows on $\mathrm{d} 16,18$, and 20 after insemination. $\beta 2$-Microglobulin, IFN regulatory factor-1, and IFN regulatory factor-2 were not different between groups. The results clearly indicated that components of the innate immune response are activated in PBL during the period of pregnancy recognition and early embryo signaling. The physiological implications of these changes on maternal immune function are as yet unknown; however, they do provide a unique oppor-

Received July 27, 2006.

Accepted August 23, 2006.

${ }^{1}$ Corresponding author: tlo12@psu.edu tunity to identify bred, nonpregnant, cows $18 \mathrm{~d}$ after insemination in dairy cattle.

Key words: pregnancy, dairy, interferon, leukocyte

\section{INTRODUCTION}

It is generally accepted that pregnancy recognition signaling in domestic ruminants is a local phenomenon involving IFN- $\tau$ from the conceptus that acts on the uterine endometrium to alter gene expression (reviewed by Spencer and Bazer, 2004). This interaction abrogates luteolytic pulses of $\mathrm{PGF}_{2 \alpha}$, resulting in the maintenance of a functioning corpus luteum. This is in contrast to humans, in whom conceptus-produced chorionic gondadotropin directly supports corpus luteum function and can be measured in maternal circulation as soon as 6 to $7 \mathrm{~d}$ following fertilization (Bazer et al., 1998). In fact, the presence of this hormone in the periphery is the basis for the widely used human home pregnancy test.

The first conceptus-produced factor that can be reliably measured as an indicator of pregnancy status in the peripheral circulation of the pregnant cow is the glycoprotein hormone, pregnancy-specific protein B (also known as pregnancy-associated glycoprotein; Butler et al., 1982). The presence of pregnancy-specific protein B in maternal blood $30 \mathrm{~d}$ after successful mating is a reliable indicator of pregnancy status in cattle (Sasser et al., 1986). Recent work from our laboratory, however, demonstrated that the presence of a viable conceptus in sheep can be assessed indirectly by measuring levels of the IFN-stimulated gene (ISG) Mx1 in maternal peripheral blood leukocytes (PBL) $15 \mathrm{~d}$ after insemination (Yankey et al., 2001). More important, absence of this increase in $\mathrm{Mx} 1$ in the PBL was diagnostic of inseminated ewes that failed to conceive. The timing of this increase is important because it occurred before the animal was expected to return to estrus.

The Mx1 gene is a member of the ISG family with well-known antiviral properties (Lee and Vidal, 2002). More than 100 ISG are known (Samuel, 1991; Garcia- 
Sastre and Biron, 2006), and a number of these have been shown to increase in the uterus during pregnancy recognition, including $2^{\prime} 5^{\prime}$ oligoadenylate synthetase (Johnson et al., 2001), $\beta 2$-microglobulin ( $\beta 2$-MG; Vallet et al., 1991), ISG-15 (Austin et al., 1996, 2004), and Mx1 (Charleston and Stewart, 1993; Ott et al., 1998; Johnson et al., 2001; Hicks et al., 2003). The role ISG play in uterine function is the subject of active investigation.

Lower levels of ISG in the blood of nonpregnant dairy cattle, when compared with pregnant cows, prior to the onset of the next estrus would allow early identification of nonpregnant cows in time to allow for resynchronization and rebreeding at the next estrus (Lucy et al., 2004). In essence, open cows detected using this approach would be inseminated every cycle. This could substantially reduce the interval from calving to conception. Therefore, the present study tested the hypothesis that mRNA levels for members of the ISG family increase in PBL at $\mathrm{d} 18$ following insemination in dairy cattle, and that a lack of increase in these genes was diagnostic of inseminated cows that failed to establish or maintain pregnancy.

\section{MATERIALS AND METHODS}

\section{Animals}

All cows were housed and maintained at the University of Idaho Dairy Center, and all procedures were approved by the University of Idaho Animal Care and Use Committee. Fifty Holstein cows were synchronized to estrus (Ovsynch; Pursley et al., 1995) and inseminated (d 0). Blood samples were collected (coccygeal venipuncture) at d 0 and 16, 18, and $20 \mathrm{~d}$ after insemination. Pregnancy was confirmed via transrectal ultrasonography at 40 to $45 \mathrm{~d}$ after breeding.

\section{Blood Sample Processing}

For serum harvest, blood samples were collected into Corvax serum separator tubes (Tyco Healthcare Group LP, Mansfield, MA) and allowed to clot overnight at $4^{\circ} \mathrm{C}$. Serum tubes were then centrifuged at $1,500 \times g$ for 15 min at $4^{\circ} \mathrm{C}$, and serum was collected and frozen at $-20^{\circ} \mathrm{C}$. Serum progesterone was quantified by RIA at the University of Idaho/Washington State University Center for Reproductive Biology Hormone Assay Core (Washington State University). Serum progesterone was assayed to ensure that estrus synchronization was achieved, and only cows that had progesterone values less than $1 \mathrm{ng} /$ $\mathrm{mL}$ at breeding were included in the study.

Blood samples for RNA extraction were collected into EDTA-containing tubes (Tyco Healthcare Group LP) and immediately placed on ice until processing. Tubes were centrifuged at $1,200 \times g$ for $12 \mathrm{~min}$ at $4^{\circ} \mathrm{C}$, and buffy coat fractions were collected and transferred to $15-\mathrm{mL}$ conical tubes. Twelve to $15 \mathrm{~mL}$ of red blood cell lysis buffer $\left(150 \mathrm{mM} \mathrm{NH} \mathrm{NH}_{4} \mathrm{Cl}, 10 \mathrm{~m} M \mathrm{NaHCO}_{3}, 1 \mathrm{~m} M\right.$ EDTA, $\mathrm{pH}$ 7) was added to the buffy coat, and tubes were inverted several times, followed by incubation at room temperature for $5 \mathrm{~min}$. Samples were then centrifuged at $300 \times g$ for $10 \mathrm{~min}$ at $4^{\circ} \mathrm{C}$ to isolate $\mathrm{PBL}$, and the supernatant was discarded. The PBL pellet was then mixed with $5 \mathrm{~mL}$ of red blood cell lysis buffer, incubated at room temperature, and centrifuged at $300 \times g$ for 10 min at $4^{\circ} \mathrm{C}$, and the supernatant was discarded. The PBL pellet was then washed with ice-cold $1 \times$ PBS and centrifuged at $300 \times g$ for $10 \mathrm{~min}$ at $4^{\circ} \mathrm{C}$, and the supernatant was discarded. The PBL pellet was resuspended with residual PBS, and $2 \mathrm{~mL}$ of Trizol (Invitrogen, Carlsbad, CA) was added to each sample. Cells were lysed by gently pipetting up and down, and the samples were evenly divided between two $1.5-\mathrm{mL}$ microcentrifuge tubes and stored at $-80^{\circ} \mathrm{C}$ until assayed.

\section{RNA Extraction and cDNA Synthesis}

Ribonucleic acid was extracted and purified using Trizol according to the manufacturer's recommendations. For cDNA synthesis, $5 \mu \mathrm{g}$ of total RNA was incubated with $1 \mu \mathrm{L}$ of RQ1 DNase (Promega, Madison, WI) and $1 \mu \mathrm{L}$ of Strata Script RT buffer (Stratagene, La Jolla, CA) in $8 \mu \mathrm{L}$ total volume at $37^{\circ} \mathrm{C}$ for $30 \mathrm{~min}$. One microliter of DNase stop solution (Promega) was added, and samples were incubated at $65^{\circ} \mathrm{C}$ for $10 \mathrm{~min}$. Three microliters of random primers (Invitrogen) and $27 \mu \mathrm{L}$ of nuclease-free water was added to each sample and samples were incubated at $65^{\circ} \mathrm{C}$ for $5 \mathrm{~min}$ followed by $25^{\circ} \mathrm{C}$ for $10 \mathrm{~min}$. Nine microliters of a master mix containing $5 \mu \mathrm{L}$ of Strata Script RT buffer (Stratagene), $1 \mu \mathrm{L}$ of RNase inhibitor (Invitrogen), $2 \mu \mathrm{L}$ of $100 \mathrm{~m} M$ deoxynucleoside triphosphates (Invitrogen), and $1 \mu \mathrm{L}$ of Strata Script RT (Stratagene) was added to each sample, followed by incubation at $42^{\circ} \mathrm{C}$ for $2 \mathrm{~h}$ and $90^{\circ} \mathrm{C}$ for $5 \mathrm{~min}$. Samples were stored at $-20^{\circ} \mathrm{C}$.

\section{Quantitative Real-Time PCR}

After validation (see below), all reactions were completed using the following conditions, with the exception of annealing temperature (Table 1). A working solution of cDNA was prepared by diluting samples 1:10 with nuclease-free water. Five microliters of cDNA working solution was added to $15 \mu \mathrm{L}$ of Master Mix containing 10 $\mu \mathrm{L}$ of SYBR Green (Finnzymes DyNAmo SYBR Green qPCR Kit; New England BioLabs, Ispwich, MA), $2.5 \mu \mathrm{L}$ of forward primer $(2.4 \mu M)$, and $2.5 \mu \mathrm{L}$ of reverse primer $(2.4 \mu M)$, and the following times and temperatures were used: $95^{\circ} \mathrm{C}$ for $30 \mathrm{~s}$, annealing temperature (see Table 1 
Table 1. Gene, primer orientation, primer sequence ( $5^{\prime}$ to $\left.3^{\prime}\right)$, annealing temperature, and $\mathrm{NCBI}^{1}$ sequence for primer sets used in quantitative real-time PCR assays

\begin{tabular}{|c|c|c|c|c|}
\hline Gene & Primer & Sequence $\left(5^{\prime}\right.$ to $\left.3^{\prime}\right)$ & $\begin{array}{l}\text { Annealing } \\
\text { temperature, } \\
{ }^{\circ} \mathrm{C}\end{array}$ & $\begin{array}{l}\text { NCBI } \\
\text { sequence }\end{array}$ \\
\hline \multirow[t]{2}{*}{$\mathrm{Mx} 1$} & Forward & GTACGAGCCGAGTTCTCCAA & \multirow[t]{2}{*}{57.5} & \multirow[t]{2}{*}{ AF047692 } \\
\hline & Reverse & ATGTCCACAGCAGGCTCTTC & & \\
\hline \multirow[t]{2}{*}{ Mx2 } & Forward & CTTCAGAGACGCCTCAGTCG & \multirow[t]{2}{*}{56.5} & \multirow[t]{2}{*}{ NM_173941 } \\
\hline & Reverse & TGAAGCAGCCAGGAATAGTG & & \\
\hline \multirow[t]{2}{*}{ IFN regulatory factor- 1} & Forward & GCTGGGACATCAACAAGGAT & \multirow[t]{2}{*}{58.6} & \multirow[t]{2}{*}{ NM_177432 } \\
\hline & Reverse & СTTTCCTCTGGCTCTTGGTG & & \\
\hline \multirow[t]{2}{*}{ IFN regulatory factor-2 } & Forward & GCACATCAAGCAAGAACCAA & \multirow[t]{2}{*}{58.6} & \multirow[t]{2}{*}{ AJ490936 } \\
\hline & Reverse & GGTGGTCACCTCCACAACTT & & \\
\hline \multirow[t]{2}{*}{$\beta 2$-Microglobulin } & Forward & ACACCCACCAGAAGATGGAA & \multirow[t]{2}{*}{57.5} & \multirow[t]{2}{*}{ X69084 } \\
\hline & Reverse & TGTTTCACTCGGCAGCTGTA & & \\
\hline \multirow[t]{2}{*}{$\beta$-Actin } & Forward & CTGGACTTCGAGCAGGAGAT & \multirow[t]{2}{*}{56.5 to 58.6} & \multirow[t]{2}{*}{ AY141970 } \\
\hline & Reverse & GGATGTCGACGTCACACTTC & & \\
\hline \multirow[t]{2}{*}{ IFN-stimulated gene-15 } & Forward & GGTATCCGAGCTGAAGCAGTT & \multirow[t]{2}{*}{62.0} & \multirow[t]{2}{*}{ NM_174366 } \\
\hline & Reverse & ACCTCCCTGCTGTCAAGGT & & \\
\hline
\end{tabular}

${ }^{1} \mathrm{NCBI}=$ National Center for Biotechnology Information.

for each gene) of $30 \mathrm{~s}$, and $72^{\circ} \mathrm{C}$ for $30 \mathrm{~s}$ for 40 cycles. All samples were assayed in duplicate for each gene measured. $\beta$-Actin was also assayed in duplicate for each sample, and each gene was measured to adjust for loading errors and interplate variation. Interferon-stimulated gene-15 quantitative real-time PCR was performed using similar reaction and validation conditions, SYBR Green (Bio-Rad Laboratories, Hercules, CA), and the following times and temperatures: $95^{\circ} \mathrm{C}$ for $30 \mathrm{~s}, 62^{\circ} \mathrm{C}$ for $30 \mathrm{~s}$, and $72^{\circ} \mathrm{C}$ for $15 \mathrm{~s}$ for 40 cycles. Following reverse transcription (RT)-PCR amplification, cDNA were melted (melting curve) to ensure the quality of amplification. For the melting curve analysis, RT-PCR products were incubated for $10 \mathrm{~s}$ at each step with an increase in temperature of $0.5^{\circ} \mathrm{C}$ from $55^{\circ} \mathrm{C}$ to $95^{\circ} \mathrm{C}$ in each cycle. Notemplate and nontranscribed RNA were run as negative controls for all assays. All primers were ordered from Invitrogen and are listed in Table 1.

For quantitative real-time PCR optimization and validation, all primer sets were tested with a primer concentration gradient $(150,200,250,300$, and $350 \mathrm{n} M$ final concentrations in a $20-\mu \mathrm{L}$ reaction). The temperature and concentration that yielded the lowest critical threshold (Ct) value and highest fluorescence were used for the quantitative real-time PCR assay and validation studies. Each primer set was validated using a 7-log dilution curve. A large amplicon of each gene was generated using RT-PCR and purified using a PCR purification kit (Qiagen, Valencia, CA). A random cDNA sample was diluted 1:10 with nuclease free water and $1 \mu \mathrm{L}$ of purified PCR product; this was then diluted 1:10 seven times, and duplicates were assayed for each dilution. Threshold cycle values were then plotted (scatter plot function, Excel; Microsoft Corporation, Redmond, WA), and a line was fitted to the data to calculate $\mathrm{R}^{2}$, the $\mathrm{y}$-intercept, and the slope. Primer efficiency was then calculated as $10^{(-}$ 1/slope)-1. The efficiency of each primer set was calculated, and values were between 90 and 105\% (data not shown). Only $\mathrm{Ct}$ values that fell within the range of the 7-log curve were accepted for sample data analysis.

\section{Statistical Analyses}

All data were analyzed using the MIXED procedure in SAS (Version 9.1; SAS Institute, Cary, NC) for repeated measures. Animal was the experimental unit and fold change of dependent variables was tested against status, day, and status $\times$ day. When significant status $\times$ day interactions were detected, variables were analyzed within day. Data are presented as least squares mean \pm standard error of the mean of relative fold change from d 0 calculated by the $\Delta \Delta \mathrm{Ct}$ method (reviewed by Kubista et al., 2006), with $\beta$-actin serving as the internal control.

\section{RESULTS}

Progesterone values for pregnant $(\mathrm{n}=20)$ and bred, nonpregnant cows $(\mathrm{n}=30)$ are represented in Figure 1. Progesterone was similar for pregnant and bred, nonpregnant cows through d 18 after insemination. However, progesterone decreased $(P<0.05)$ and was $2.8 \pm$ $0.4 \mathrm{ng} / \mathrm{mL}$ in bred, nonpregnant cows compared with 5.1 $\pm 0.4 \mathrm{ng} / \mathrm{mL}$ for pregnant cows $20 \mathrm{~d}$ after insemination.

A status $\times$ day interaction was detected $(P<0.05)$ for Mx1 mRNA levels for pregnant and bred, nonpregnant cows. Levels of Mx1 mRNA were similar $(P>0.10)$ between pregnant and bred, nonpregnant cows on d 16 and 18 after insemination. However, $\mathrm{Mx} 1 \mathrm{mRNA}$ levels increased $(P<0.05)$ greater than 2 -fold on d 20 in pregnant cows compared with approximately 1.5 -fold in bred, 


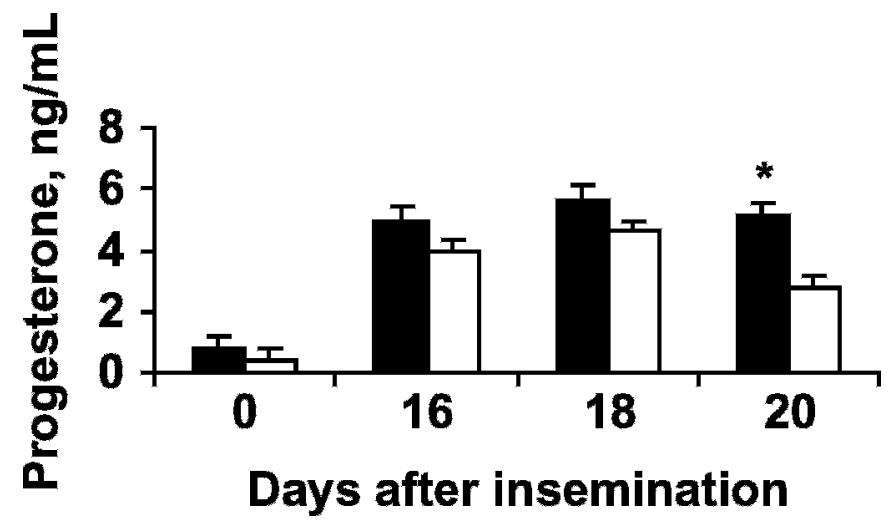

Figure 1. Serum progesterone for pregnant (closed bars; $n=20$ ) and bred, nonpregnant (open bars; $\mathrm{n}=30$ ) dairy cows. Cows were synchronized to estrus, and samples were collected at insemination and 16,18 , and $20 \mathrm{~d}$ after insemination. $* P<0.05$. Error bars represent treatment SEM.

nonpregnant cows (Figure 2). Likewise, a status $\times$ day interaction was detected $(P<0.05)$ for $\mathrm{Mx} 2$. In bred, nonpregnant cows, Mx2 mRNA levels remained relatively constant, with an average 1 - to 1.5 -fold increase (compared with d 0) on d 16, 18, and 20. However, $\mathrm{Mx} 2$ mRNA increased $(P<0.05)$ to approximately $2-, 4-$, and 5 -fold on d 16,18 , and 20 , respectively, in pregnant cows (Figure 2).

Because of the limited amounts of RNA, a subset of 8 pregnant and 21 bred, nonpregnant, cows was used to quantify steady-state mRNA levels of ISG-15, $\beta 2$-MG, IFN regulatory factor-1 (IRF-1), and IRF-2. Interestingly, $\beta 2-\mathrm{MG}$ mRNA levels were similar $(P>0.10)$ in pregnant and bred, nonpregnant cows on $\mathrm{d} 16,18$, and 20 for both groups (Figure 3). Conversely, a status $\times$ day interaction was detected $(P<0.05)$ for ISG-15. Bred, nonpregnant dairy cows showed little change in ISG-15 mRNA between d 16, 18, and 20 after insemination. For pregnant cows, ISG-15 mRNA levels were elevated by over 2 -fold $(P<0.05)$ on d 18 and increased to 5 -fold above bred, nonpregnant cows $(P<0.05)$ by d 20 (Figure 3 ).

To determine whether transcription factors associated with IFN- $\tau$ signaling were affected by status, steadystate mRNA levels of IRF-1 and IRF-2 in PBL were quantified in the subset of pregnant and bred, nonpregnant dairy cows. Figure 4 shows the fold change of IRF1 and IRF-2 in pregnant and bred, nonpregnant cows on d 16, 18, and 20 after insemination. Levels of IRF-1 and IRF-2 mRNA were similar $(P>0.10)$ for the 2 groups and were not different from d 0 on $\mathrm{d} 16,18$, and 20 .

\section{DISCUSSION}

Interferon- $\tau$ from the blastocyst ( $\mathrm{d} 15$ to 16 after breeding in cows) alters gene expression in the uterus to allow

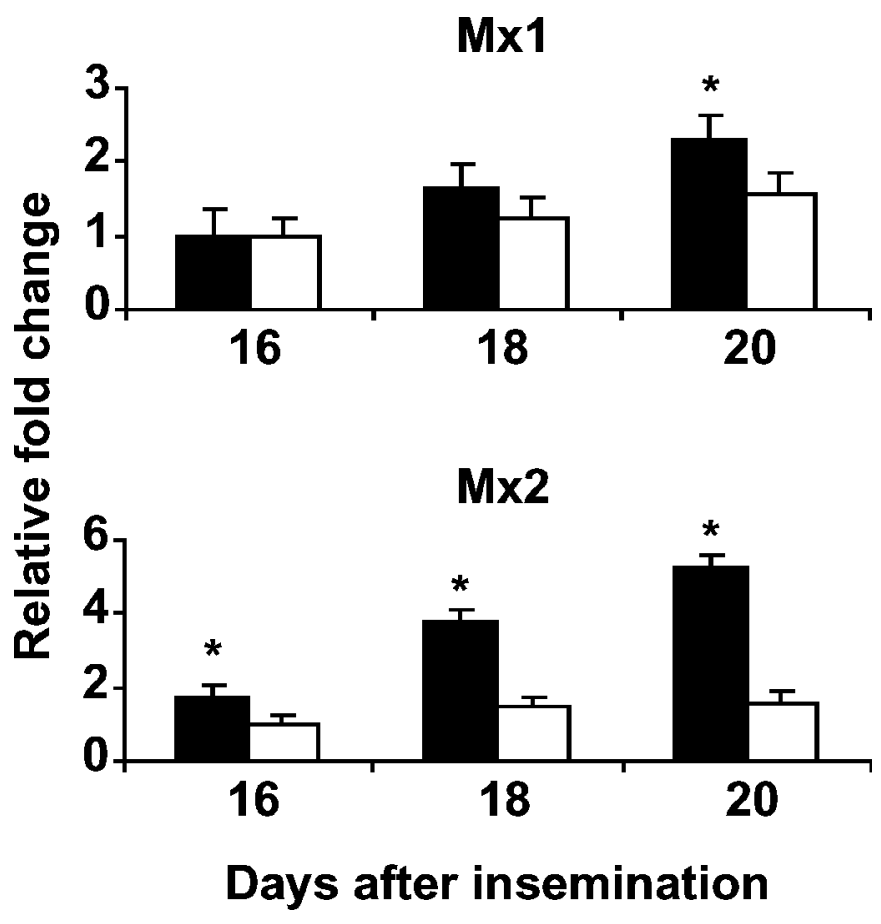

Figure 2. Steady-state mRNA levels for Mx1 (top) and Mx2 (bottom) were quantified using quantitative real-time PCR in pregnant (closed bars; $\mathrm{n}=20$ ) and bred, nonpregnant (open bars; $\mathrm{n}=30$ ) dairy cows. Cows were synchronized to estrus, and samples were collected at insemination (d 0) and 16, 18, and $20 \mathrm{~d}$ after insemination. Bars represent the average fold change from $d 0$ calculated using the $\Delta \Delta$ critical threshold method. $* P<0.05$. Error bars represent treatment SEM.

for successful pregnancy (reviewed by Spencer and Bazer, 2004). It has been established that IFN- $\tau$ increases expression of ISG in the endometrium in pregnant sheep and cattle; however, it has only recently been shown that ISG are induced systemically within days of blastocyst signaling in ewes (Yankey et al., 2001). The present study demonstrated that steady-state mRNA levels for Mx2 increased as early as $16 \mathrm{~d}$ after insemination, $18 \mathrm{~d}$ after insemination for ISG-15, and $20 \mathrm{~d}$ for $\mathrm{Mx} 1$ in PBL isolated from pregnant cows. Although $\mathrm{Mx} 1$ is a known antiviral protein, the function of Mx2 has not been elucidated (MacMicking, 2004). Interestingly, Mx2 appears to be more strongly regulated in PBL by pregnancy than $\mathrm{Mx} 1$, showing an earlier (d 16) and a greater induction (over 5-fold on d 20) in pregnant vs. bred, nonpregnant cows. In contrast, $\mathrm{Mx} 1 \mathrm{mRNA}$ levels were not different $(P<0.05)$ until d 20 in pregnant cows, compared with bred, nonpregnant cows. Likewise, ISG15 increased and was greater $(P<0.05)$ on d 18 in pregnant cows, compared with bred, nonpregnant cows. The results clearly indicate that components of the innate immune system are activated in circulating leukocytes during early pregnancy in dairy cattle. 
ISG-15

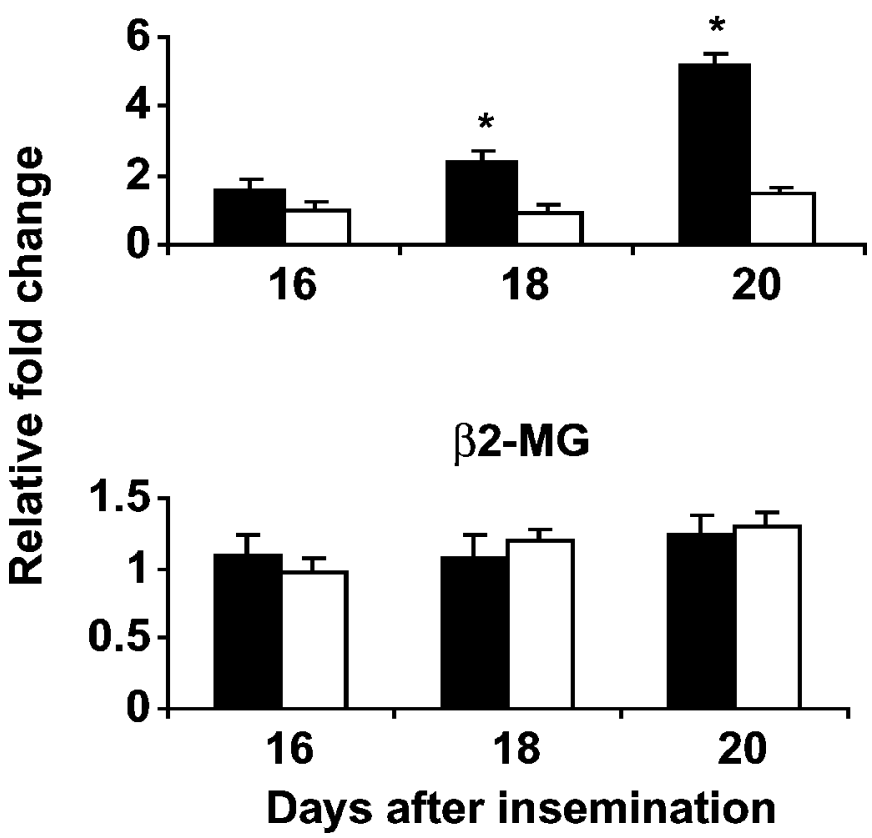

Figure 3. Steady-state mRNA levels for interferon-stimulated gene-15 (ISG- 15 ; top) and $\beta 2$-microglobulin ( $\beta 2$-MG; bottom) were quantified using quantitative real-time PCR in pregnant (closed bars; $\mathrm{n}=8$ ) and bred, nonpregnant (open bars; $\mathrm{n}=21$ ) dairy cows. Cows were synchronized to estrus, and samples were collected at insemination (d 0 ) and 16,18 , and $20 \mathrm{~d}$ after insemination. Bars represent the average fold change from d 0 calculated using the $\Delta \Delta$ critical threshold method. $* P<0.05$. Error bars represent treatment SEM.

The mechanism by which ISG are activated in the periphery during early pregnancy is unclear. Until recently, IFN- $\tau$ was thought to act in a paracrine manner exclusively in the endometrium (Vallet et al., 1991; Spencer et al., 1998; Johnson et al., 2000; Charleston and Stewart, 1993; Ott et al., 1998). More recently, however, Dixit and Pavizi (2001) showed increases in adrenocorticotropin and nitric oxide in bovine PBL as early as d 7 of pregnancy, although IFN- $\tau$ was apparently not involved in this response. Granulocyte-macrophage colony-stimulating factor gene expression was increased by IFN- $\tau$ in cultured bovine PBL (Edmond et al., 2000), but there was no evidence that pregnancy resulted in changes in granulocyte-macrophage colony-stimulating factor expression in PBL in vivo.

In the present study, IRF-1 and IRF-2 expression were not different in pregnant and bred, nonpregnant cows. One possible interpretation of these results is that factors other than IFN- $\tau$ may be responsible for systemic activation of ISG. It is also possible that the sampling regimen was not optimal for detecting changes in these transcription factors. Both IRF-1 and IRF-2 show complex spatial and temporal regulation in the uterus (Choi

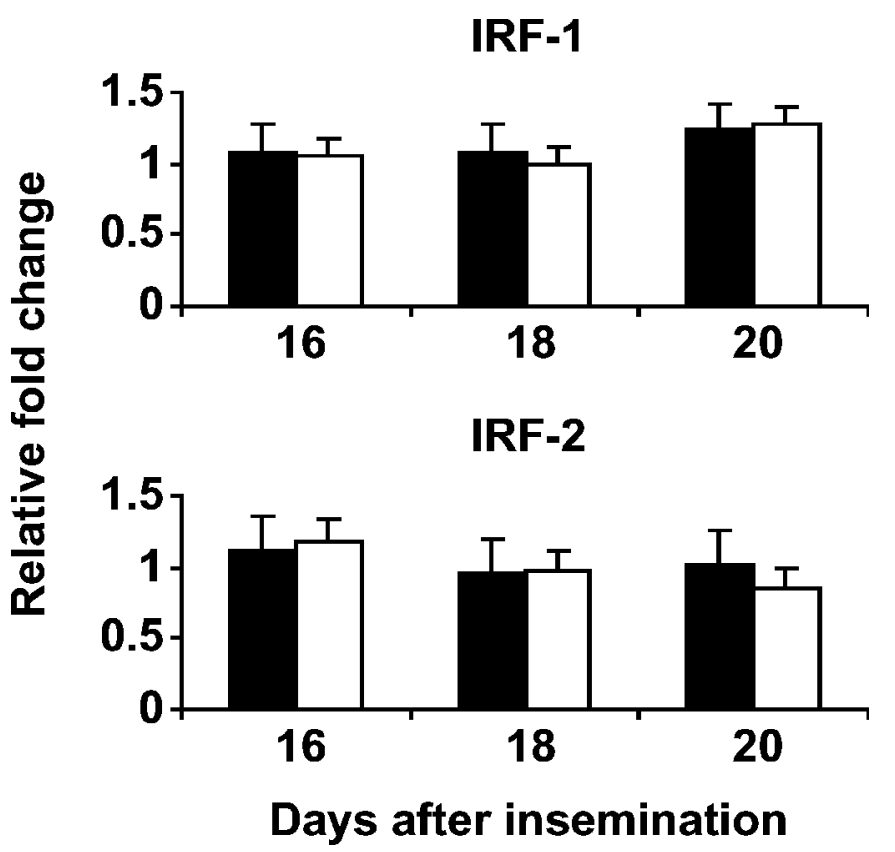

Figure 4. Steady-state mRNA levels for IFN regulatory factor-1 (IRF-1; top) and IRF-2 (bottom) were quantified using quantitative real-time PCR in pregnant (closed bars; $\mathrm{n}=8$ ) and bred, nonpregnant (open bars; $n=21$ ) dairy cows. Cows were synchronized to estrus, and samples were collected at insemination (d 0) and 16, 18, and 20 $\mathrm{d}$ after insemination. Bars represent the average fold change from d 0 calculated using the $\Delta \Delta$ critical threshold method. Error bars represent treatment SEM.

et al., 2001). Interferon regulatory factor- $2 \mathrm{mRNA}$ and protein increased from $\mathrm{d} 11$ to 15 in the luminal and superficial glandular epithelium of the ovine endometrium (Choi et al., 2001). However, IFN- $\tau$ infusions into the uterus of cyclic ewes did not increase IRF-2 mRNA or protein levels (Choi et al., 2001). Levels of IRF-1 were increased in the endometrium from d 11 to 15 as well, but not in the luminal and superficial glandular epithelium (Choi et al., 2001). Also, our assay may not have been sensitive enough to detect small changes in these ISG. Similarly, we did not detect elevation in $\beta 2-\mathrm{MG}$ in the PBL, yet $\beta 2-\mathrm{MG}$ was shown to be increased by IFN- $\tau$ in the uterus (Vallet et al., 1991). Once again, our sampling regimen was optimized to detect changes in Mx and ISG15 gene expression based on our previous work in sheep (Yankey et al., 2001) and on our unpublished observations in dairy cattle. It is possible that with earlier, later, or more frequent sampling, changes in the above ISG would be detected.

In humans during early pregnancy, the innate arm of the immune system is activated to levels near systemic sepsis, presumably to protect the mother, because other components of the immune system must be suppressed to allow implantation of the semiallogenic conceptus (reviewed by Sacks et al., 1999). A similar phenomenon 
may occur in ruminants to provide a counterbalance to the immunomodulatory actions of progesterone (Gill, 1985). In addition, systemic gene expression changes during early pregnancy may aid in establishing pregnancy. Nakayama et al. (2002) provided evidence of promoting effects of immune cells on early events of embryo implantation by showing that peripheral blood mononuclear cells isolated from pregnant humans enhanced murine embryo spreading and invasion in vitro. Moreover, Kosaka et al. (2003) showed that peripheral blood mononuclear cells promoted attachment of BeWo-cell spheroids to endometrial cells derived from human uteri in the late proliferative and early secretory phases, indicating that peripheral blood mononuclear cells may be able to induce endometrial cells to become "receptive" to an embryo. Thus, only recently has information on the active roles that PBL may have in implantation and early pregnancy been reported.

In addition to revealing components of the maternal immune response to early pregnancy, systemic activation of ISG may provide an opportunity to identify open cows before their expected return to estrus (Yankey et al., 2001). Santos et al. (2004) reviewed several studies that showed fertilization rates that were lower than previously thought $(76 \%$ for lactating and nonlactating dairy cows) and 40 to $50 \%$ embryo loss 5 to $6 \mathrm{~d}$ after insemination. Thus, 64 to $74 \%$ of cows bred may not be pregnant 5 to $6 \mathrm{~d}$ after insemination. Conventional ultrasonographic methods cannot determine pregnancy status until approximately $\mathrm{d} 26$, and palpation is ineffective until approximately d 35 (Kastelic et al., 1988). If inseminated cows that failed to conceive and maintain pregnancy were identified at d 18 to 20 , a rapid resynchronization protocol could be used (Lucy et al., 2004). Cows that were detected open at d 18 to 20 could be given $\mathrm{PGF}_{2 \alpha}$ followed by $\mathrm{GnRH} 2 \mathrm{~d}$ later and rebreeding at d 21 to 23 (Lucy et al., 2004). The advantage of this approach is that reproductive management efforts could be focused on 8 d over a 5 -wk period, and days open could be minimized (Lucy et al., 2004). By using a rapid resynchronization procedure, 2 services could occur in approximately $23 \mathrm{~d}$, which would be roughly 10 and $40 \mathrm{~d}$ earlier than occurs when detecting open cows by ultrasound or rectal palpation, respectively. Also, repeat breeders and "phantom" cows (those not expressing estrus) could be more easily identified (Lucy et al., 2004). This could potentially reduce the days open and improve the efficiency of dairy production.

Because changes in gene expression in PBL can occur rapidly after blood collection (Hartel et al., 2001), future studies are needed to identify the variability associated with changes in ISG gene expression that may be induced ex vivo. Once conditions for sample collection are optimized, larger studies are necessary to determine the percentage of inseminated, nonpregnant cows that can be identified using this technology as well as to ensure that pregnant cows are not incorrectly diagnosed as open. It should also be noted that the current study did not include a nonbred, cyclic group of cows. It is very probable that a subset of the bred, nonpregnant cows did possess a conceptus during the sampling days, resulting in elevated levels of ISG on these days. However, even without this control, differences were detected between pregnant and bred, nonpregnant cows, indicating the robustness of this technique for identification of pregnancy-specific changes in ISG in the periphery. A nonbred, cyclic control group would be beneficial in future studies to determine the effects of the changing hormonal environment on gene expression in the periphery. Nonetheless, changes in gene expression in the PBL of pregnant cows may provide an economically advantageous method of identifying inseminated, nonpregnant cows earlier than methods currently available.

In summary, these results indicate that rapid communication occurs between the conceptus and maternal immune system around the time of maternal recognition of pregnancy in dairy cows. This results in changes in gene expression that can be measured in PBL. A number of ISG are activated (Mx1, Mx2, and ISG-15), whereas others do not change ( $\beta 2-\mathrm{MG}$, IRF-1, and IRF-2). These systemic responses to pregnancy may provide clues to the immune accommodation that allows the semiallogeneic conceptus to evade maternal immune rejection without placing the dam at higher risk for disease, and also may be used to identify inseminated, nonpregnant cows prior to their expected return to estrus.

\section{REFERENCES}

Austin, K. J., A. L. Carr, J. K. Pru, C. E. Hearne, E. L. George, E. L. Belden, and T. R. Hansen. 2004. Localization of ISG15 and conjugated proteins in bovine endometrium using immunohistochemistry and electron microscopy. Endocrinology 145:967-975.

Austin, K. J., S. K. Ward, M. G. Teixeira, V. C. Dean, D. W. Moore, and T. R. Hansen. 1996. Ubiquitin cross-reactive protein is released by the bovine uterus in response to interferon during early pregnancy. Biol. Reprod. 54:600-606.

Bazer, F. W., T. L. Ott, and T. E. Spencer. 1998. Maternal recognition of pregnancy: Comparative aspects. Trophoblast Res. 12:375-386.

Butler, J. E., R. G. Sasser, C. A. Ruder, G. M. Hass, and R. J. Williams. 1982. Detection and partial characterization of two bovine pregnancy-specific proteins. Biol. Reprod. 26:925-928.

Charleston, B., and H. J. Stewart. 1993. An interferon-induced Mx protein: cDNA sequence and high-level expression in the endometrium of pregnant sheep. Gene 137:327-331.

Choi, Y., G. A. Johnson, R. C. Burghardt, L. C. Berghman, M. M. Joyce, K. M. Taylor, M. D. Stewart, F. W. Bazer, and T. E. Spencer. 2001. Interferon regulatory factor-two restricts expression of interferon-stimulated genes in the endometrial stroma and glandular epithelium of the ovine uterus. Biol. Reprod. 65:1038-1049.

Dixit, V. D., and N. Pavizi. 2001. Pregnancy stimulates secretion of adrenocorticotropin and nitric oxide from peripheral bovine lymphocytes. Biol. Reprod. 64:242-248.

Edmond, V., E. Asselin, M. A. Fortier, B. D. Murphy, and R. D. Lambert. 2000. Interferon- $\tau$ stimulates granulocyte-macrophage col- 
ony-stimulating factor gene expression in bovine lymphocytes and endometrial stromal cells. Biol. Reprod. 62:1728-1737.

Garcia-Sastre, A., and C. A. Biron. 2006. Type I Interferons and the virus-host relationship: A lesson in détente. Science 312:879-882.

Gill, T. J., III. 1985. Immunity and pregnancy. Crit. Rev. Immunol. 5:201-227.

Hartel, C., G. Bein, M. Muller-Steinhardt, and H. Kluter. 2001. Ex vivo induction of cytokine mRNA expression in human blood samples. J. Immunol. Methods 249:63-71.

Hicks, B. A., S. J. Etter, K. G. Carnahan, M. M. Joyce, A. A. Assiri, S. J. Carling, K. Kodali, G. A. Johnson, T. R. Hansen, M. A. Mirando, G. L. Woods, D. K. Vanderwall, and T. L. Ott. 2003. Expression of the uterine Mx protein in cyclic and pregnant cows, gilts, and mares. J. Anim. Sci. 81:1552-1556.

Johnson, G. A., T. E. Spencer, R. C. Burghardt, M. M. Joyce, and F. W. Bazer. 2000. Interferon- $\tau$ and progesterone regulate ubiquitin cross-reactive protein expression in the ovine uterus. Biol. Reprod. 62:622-627.

Johnson, G. A., M. D. Stewart, C. A. Gray, Y. Choi, R. C. Burghardt, L. Y. Yu-Lee, F. W. Bazer, and T. E. Spencer. 2001. Effects of the estrous cycle, pregnancy, and interferon $\tau$ on $2^{\prime}, 5^{\prime}$-oligoadenylate synthetase expression in the ovine uterus. Biol. Reprod. 64:1392-1399.

Kastelic, J. P., S. Curran, R. A. Pierson, and O. J. Ginther. 1988. Ultrasonic evaluation of the bovine conceptus. Theriogenology 29:39-43.

Kosaka, K., H. Fujiwara, K. Tatsumi, S. Yoshioka, T. Higuchi, Y. Sato, T. Nakayama, and S. Fujii. 2003. Human peripheral blood mononuclear cells enhance cell-cell interaction between human endometrial epithelial cells and BeWo-cell spheroids. Hum. Reprod. 18:19-25.

Kubista, M., J. M. Andrade, M. Bengtsson, A. Forootan, J. Jonak, K. Lind, R. Sindelka, R. Sjoback, B. Sjogreen, L. Strombom, A. Stahlberg, and N. Zoric. 2006. The real-time polymerase chain reaction. Mol. Aspects Med. 27:95-125.

Lee, S. H., and S. M. Vidal. 2002. Functional diversity of Mx proteins: Variations on a theme of host resistance to infection. Genome Res. 12:527.

Lucy, M. C., S. McDougall, and D. P. Nation. 2004. The use of hormonal treatments to improve the reproductive performance of lactating dairy cows in feedlot or pasture-based management systems. Anim. Reprod. Sci. 82-83:495-512.
MacMicking, J. D. 2004. IFN-inducible GTPases and immunity to intracellular pathogens. Trends Immunol. 25:601-609.

Nakayama, T., H. Fujiwara, M. Maeda, T. Inoue, S. Yoshioka, T. Mori, and S. Fujii. 2002. Human peripheral blood mononuclear cells in early pregnancy promote embryo invasion in vitro: hCG enhances the effects of PBMC. Hum. Reprod. 17:207-212.

Ott, T. L. J. Yin, A. A. Wiley, H. Kim, B. Gerami-Naini, T. E. Spencer, F. F. Bartol, R. C. Burghardt, and F. W. Bazer. 1998. Effects of the estrous cycle and early pregnancy on uterine expression of $\mathrm{Mx}$ protein in sheep (Ovis aries). Biol. Reprod. 59:784-794.

Pursley, J. R., M. O. Mee, and M. C. Wiltbank. 1995. Synchronization of ovulation in dairy cows using $\mathrm{PGF}_{2 \alpha}$ and $\mathrm{GnRH}$. Theriogenology 44:915-923.

Sacks, G. I., I. Sargent, and C. Redman. 1999. An innate view of human pregnancy. Immunol. Today 20:114-118.

Samuel, C. E. 1991. Antiviral actions of interferons: Interferon-regulated cellular proteins and their surprisingly selective antiviral activities. Virology 183:1-11.

Santos, J. E., W. W. Thatcher, R. C. Chebel, R. L. Cerri, and K. N. Galvao. 2004. The effect of embryonic death rates in cattle on the efficacy of estrus synchronization programs. Anim. Reprod. Sci. 82-83:513-535.

Sasser, R. G., C. A. Ruder, K. A. Ivani, J. E. Butler, and W. C. Hamilton. 1986. Detection of pregnancy in radioimmunoassay of a novel pregnancy-specific protein in serum of cows and a profile of serum concentrations during gestation. Biol. Reprod. 35:936-940.

Spencer, T. E., and F. W. Bazer. 2004. Conceptus signals for establishment and maintenance of pregnancy. Reprod. Biol. Endocrinol. $2: 49-63$.

Spencer, T. E., T. L. Ott, and F. W. Bazer. 1998. Expression of interferon regulatory factors one and two in the ovine endometrium: Effects of pregnancy and ovine interferon $\tau$. Biol. Reprod. 58:1154-1162.

Stark, G. R., I. M. Kerr, B. R. Williams, R. H. Siverman, and R. D. Schreiber. 1998. How cells respond to interferons. Annu. Rev. Biochem. 7:227-264.

Vallet, J. L., P. J. Barker, G. E. Lamming, N. Skinner, and N. S. Huskisson. 1991. A low molecular weight protein which is increased by ovine trophoblast protein- 1 is a $\beta 2$-microglobulin-like protein. J. Endocrinol. 130:R1-R4.

Yankey, S. J., B. A. Hicks, K. G. Carnahan, A. M. Assiri, S. J. Sinor, K. Kodali, J. N. Stellflug, and T. L. Ott. 2001. Expression of the antiviral protein $\mathrm{Mx}$ in peripheral blood mononuclear cells of pregnant and bred, non-pregnant ewes. J. Endocrinol. 170:R7-R11. 